\title{
Recent International Evolution of the Cross-border M\&A
}

\author{
Chikashi Tsuji ${ }^{1}$ \\ ${ }^{1}$ Faculty of Economics, Chuo University, Tokyo, Japan \\ Correspondence: Chikashi Tsuji, Professor, Faculty of Economics, Chuo University, 742-1 Higashinakano \\ Hachioji-shi, Tokyo 192-0393, Japan. Tel: 81-42-674-2211. E-mail: mail_sec_low@minos.ocn.ne.jp
}

Received: February 21, 2015

Accepted: March 9, $2015 \quad$ Online Published: March 23, 2015

doi:10.5430/jms.v6n2p1

URL: http://dx.doi.org/10.5430/jms.v6n2p1

\begin{abstract}
This paper constructs and examines the several ratios, presenting the state of the evolution of international cross-border mergers and acquisitions (M\&As). Our investigations as to 28 international countries reveal the following interesting evidence. First, over the four years from 2010 to 2013, larger amounts of acquired companies are observed in the six countries of the US, UK, Canada, Australia, Brazil, and Germany. Second, over the same four years, larger amounts of acquiring companies are observed in the six countries of the US, UK, Japan, Canada, France, and China. Finally, companies in Japan and China execute larger amounts of cross-border mergers as bidders whilst Australian and Brazilian firms are generally bought by the other countries' firms in the recent cross-border M\&As.
\end{abstract}

Keywords: cross-border M\&A, international mergers

\section{Introduction}

The cross-border mergers and acquisitions $(M \& A)$ is one of the most exciting topics both for business and academic professionals. In practice, which countries are executing larger amounts of cross-border M\&As in the recent years? How do the recent academic studies on M\&As evolve? For example, Deng and Yang (2015) analyzed a large panel data of cross-border M\&As conducted by emerging market firms. Focusing on the UK firms that had acquired North American and European firms, Ahammad et al. (2015) found that knowledge transfers and employee retentions positively affected cross-border acquisition performances. Andriosopoulos and Yang (2015) studied the impact of institutional ownership on the UK's M\&As and they found that institutional investors raised the likelihood of an M\&A to be a large, cross-border deal. Further, Dunn et al. (2015) researched the merger activities of non-government-assisted US commercial banks before and during financial crisis in the recent years, and they suggested that, for the crisis period mergers, valuation discrepancies between target firms and acquirers were larger.

As above, detailed academic studies are indeed important and interesting whilst a survey that supplies some new broad international viewpoints on M\&As shall be also informative and useful for smooth entire understanding of the recent state and evolution of the cross-border M\&As in the world. Based on the motivation above, this paper aims to provide useful information with regard to the cross-border M\&As in 28 international countries. Our analyses as to those international countries reveal the following interesting evidence. 1) First, over the four years from 2010 to 2013, larger amounts of acquired companies are observed in the US, UK, Canada, Australia, Brazil, and Germany. 2) Second, we also find that over the same four years, larger amounts of acquiring companies are seen in the US, UK, Japan, Canada, France, and China. 3) Further, the Japanese and Chinese corporations generally execute larger amounts of international mergers as bidders whilst Australian and Brazilian firms are bought by the other countries' firms in cross-border M\&As. The rest of the paper is organized as follows. Section 2 conducts the reviews of the recent literature, Section 3 describes our data and variables, Section 4 explains the international evidence, and Section 5 summarizes the paper.

\section{Literature Review}

This section reviews related literature by focusing only on very recent studies. First, Gregory and O'Donohoe (2014) explored the determinants of short-term wealth effects for both public acquiring and target shareholders subsequent to the announcements of UK acquisitions, which were executed over the period from 1990 to 2005. Their analyses found that all targets significantly gained from the deals; however when bid characteristics are controlled, the higher gains from international deals disappeared. Francis et al. (2014) investigated the determinants of the selections of financial advisors and their impact on the announcement effects of the US acquirers in cross-border M\&As. Their 
analyses revealed that, in cross-border M\&As, both the US acquirers and shareholders valued the certification role of financial advisors. Further, Blonigen et al. (2014) developed a model of cross-border M\&A activity, and using the model, they analyzed the firm-level productivity shocks and endogenous export activities. Chung et al. (2014) also suggested a theoretical model to explain the process through which employees adapt to changes caused by cross-border M\&As. They conducted empirical analyses by using the data of Chinese employees as well. Du and Boateng (2015) examined the effects of institutional influence and the state of ownership on value creation through cross-border M\&As executed by Chinese corporations. They found that Chinese bidders experienced gains ranging from 0.4771 percent to 1.5210 percent over a 10 -day event window.

Moreover, Deng and Yang (2015) investigated a large panel data of cross-border M\&As executed by emerging market corporations over the three years from 2000 to 2012. Their focus was on the point whether the M\&As' resource dependence logic provided a unique perspective in better understanding the globalization of emerging market corporations by cross-border M\&As. A study by Lee et al. (2015) investigated how employees from acquiring and acquired corporations experienced cultural differences during the periods of post-acquisition integration. Andriosopoulos and Yang (2015) investigated the impact of institutional ownership on the UK's M\&As and they found that institutional investors increased the likelihood of an M\&A to be a large, cross-border deal. In addition, Dunn et al. (2015) studied the non-government-assisted US commercial banks' merger activities, which were prior to and during the financial crisis in the recent years. Their analyses suggested that, for mergers prior to and during the recent financial crisis, valuation discrepancies between targets and acquirers were greater. A study by Zhu et al. (2015) considered whether high-technology corporations created value in international M\&As. Their investigations found that the acquiring companies in service information technology industries outperformed the acquirers in manufacturing industries.

Further, using the survey data as to UK firms that had acquired North American and European companies, Ahammad et al. (2015) revealed that employee retentions and knowledge transfers had a positive effect on the performances of cross-border acquisitions. Ning et al. (2014) examined the stock price reactions to the announcements of cross-border M\&As, which were executed from 1991 to 2010 by Chinese multinational enterprises listed on the Hong Kong Stock Exchange, and they also investigated the wealth effects of their corporate governance. Their empirical results showed a positive stock price reaction on average, and their results also suggested that international investors reacted positively to the presence of large shareholders, but negatively to the presence of institutional shareholders. Further, Bauer et al. (2015) examined the innovation-driven M\&As in the German-speaking area of Europe, and they found different effects of human and task integrations on the innovation outcomes after the transactions. Moreover, Angwin et al. (2015) considered why organizations rejected favorable opportunities in M\&As by investigating the companies that failed to proceed with major opportunities for strategic renewal. By focusing on routines in 28 cases of reverse M\&A decisions across three continents, they clarified the centrality of a hitherto overlooked process, the authorization routine. The above detailed studies are indeed interesting whilst this study aims to provide more simple and clear outlook, which is also informative for understanding the recent international M\&As.

\section{Data}

In this study, we use international cross-border M\&A data, which were supplied by the Japan external trade organization (JETRO). Our data cover 28 international countries and more specifically, we analyze the recent cross-border M\&As of the US, Canada, UK, France, Germany, Italy, Belgium, Netherlands, Switzerland, Norway, Japan, Australia, China, Hong Kong, Korea, Taiwan, Thailand, Singapore, Malaysia, Indonesia, India, Russia, Mexico, Colombia, Brazil, Chile, United Arab Emirates (UAE), and South Africa.

In our analyses, we focus on the following aspects. First, we compare 1) the ratio of the amount of acquired companies of each country to the total amount of acquired companies in the world from 2010 to 2013. Figure 1 shows the ratios graphically and Table 1 displays the values of the ratios in percent. Second, we analyze 2) the ratio of the amount of acquiring companies of each country to the total amount of acquiring companies in the world from 2010 to 2013. Figure 2 exhibits the ratios graphically and Table 2 shows the values of the ratios in percent. Third, we also compare 3) the change rates of the ratio of the amount of acquiring companies of each country to the total amount of acquiring companies in the world from 2011 to 2013. Figure 3 shows the change rates graphically and Table 3 exhibits the values of the rates in percent. Moreover, we further analyze 4) the differences between the ratio of the amount of acquiring companies of each country to the total amount of acquiring companies in the world and the ratio of the amount of acquired companies of each country to the total amount of acquired companies in the world. We examine the differences over the four years from 2010 to 2013. Figure 4 displays the differences graphically and Table 4 exhibits the values of the differences in percent. 


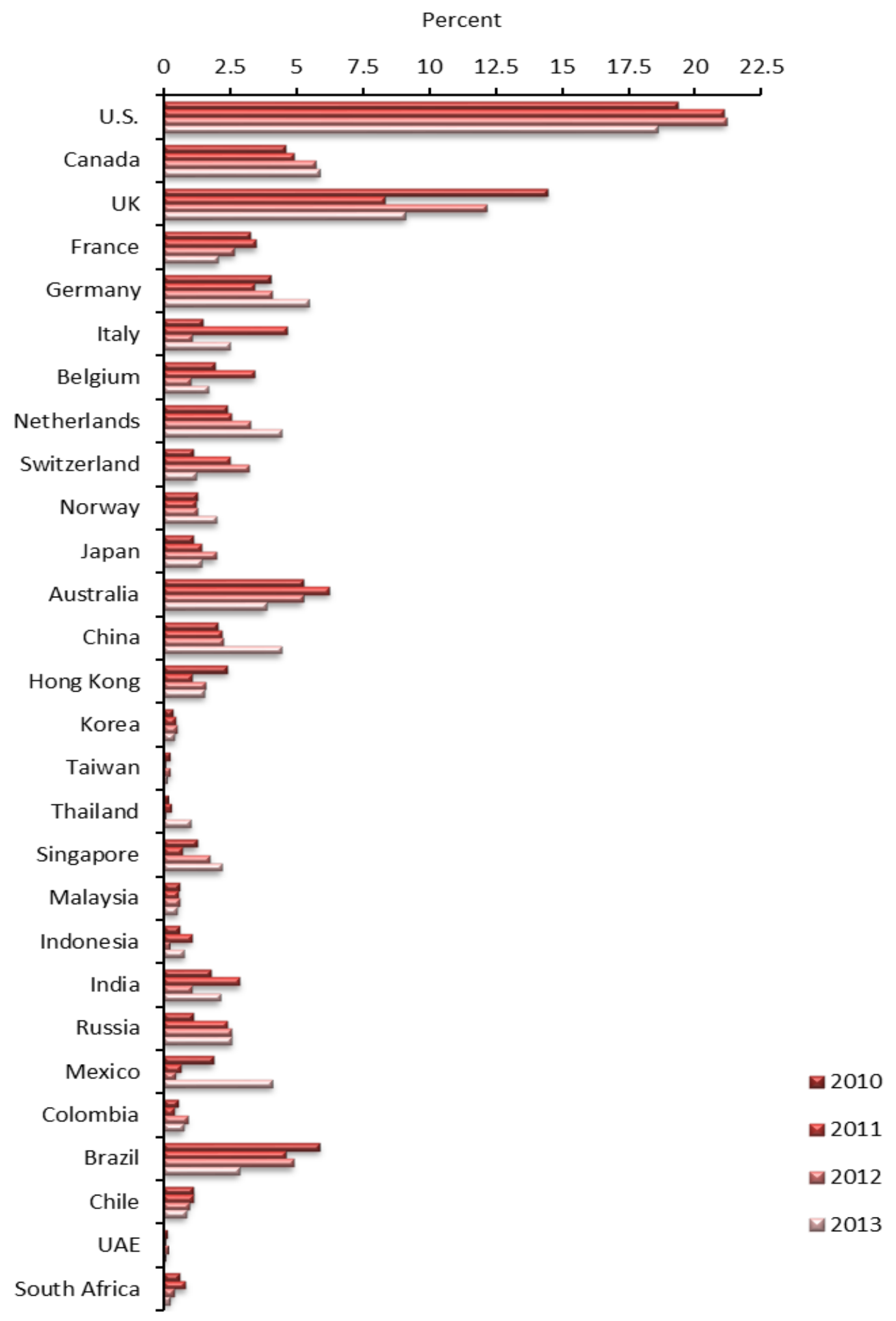

Figure 1. The ratios of the amount of acquired firms of each country to the total amount of acquired firms in the world: The international cases of 28 countries 
Table 1 . The ratios of the amount of acquired companies of each country to the total amount of acquired companies in the world: 28 international cases from 2010 to 2013

\begin{tabular}{|c|c|c|c|c|}
\hline & \multicolumn{4}{|c|}{ Years } \\
\hline Countries & 2010 & 2011 & 2012 & 2013 \\
\hline U.S. & 19.3224 & 21.0650 & 21.1637 & 18.5719 \\
\hline Canada & 4.5672 & 4.8771 & 5.7183 & 5.8394 \\
\hline UK & 14.4458 & 8.2831 & 12.1399 & 9.0847 \\
\hline France & 3.2404 & 3.4695 & 2.6570 & 2.0463 \\
\hline Germany & 4.0319 & 3.3783 & 4.0517 & 5.4691 \\
\hline Italy & 1.4463 & 4.6311 & 1.0350 & 2.4767 \\
\hline Belgium & 1.9016 & 3.4215 & 1.0209 & 1.6655 \\
\hline Netherlands & 2.4031 & 2.5137 & 3.2311 & 4.4064 \\
\hline Switzerland & 1.0882 & 2.4845 & 3.1819 & 1.2034 \\
\hline Norway & 1.2699 & 1.1811 & 1.2359 & 1.9713 \\
\hline Japan & 1.1182 & 1.3982 & 1.9539 & 1.4016 \\
\hline Australia & 5.2563 & 6.2287 & 5.2399 & 3.8355 \\
\hline China & 2.0473 & 2.1563 & 2.2247 & 4.4018 \\
\hline Hong Kong & 2.3883 & 1.0308 & 1.5367 & 1.5353 \\
\hline Korea & 0.3388 & 0.4434 & 0.4940 & 0.3982 \\
\hline Taiwan & 0.2407 & 0.0634 & 0.2433 & 0.1072 \\
\hline Thailand & 0.1701 & 0.2666 & 0.0619 & 1.0036 \\
\hline Singapore & 1.2544 & 0.6750 & 1.7328 & 2.1683 \\
\hline Malaysia & 0.5739 & 0.5449 & 0.5788 & 0.5027 \\
\hline Indonesia & 0.5850 & 1.0368 & 0.2153 & 0.7665 \\
\hline India & 1.7525 & 2.8615 & 1.0264 & 2.1211 \\
\hline Russia & 1.0830 & 2.3571 & 2.5463 & 2.5393 \\
\hline Mexico & 1.8639 & 0.6218 & 0.4134 & 4.0874 \\
\hline Colombia & 0.5271 & 0.4066 & 0.8979 & 0.7198 \\
\hline Brazil & 5.8659 & 4.5863 & 4.8633 & 2.8359 \\
\hline Chile & 1.1189 & 1.1120 & 0.9384 & 0.8254 \\
\hline UAE & 0.1522 & 0.0578 & 0.1650 & 0.0855 \\
\hline South Africa & 0.5760 & 0.8178 & 0.3858 & 0.2219 \\
\hline
\end{tabular}

Notes: This table provides the global information with regard to the cross-border M\&As in international countries. More specifically, this table presents the ratios of the amount of acquired companies of each country to the total amount of acquired companies in the world. Information in this table is concerning the M\&As of 28 countries in the areas of North America, South America, Europe, Asia-Pacific, Russia, Middle East, and Africa. Moreover, the sample period is over the four years from 2010 to 2013. In this table, UAE denotes the United Arab Emirates and all values displayed in this table are presented in percent. 


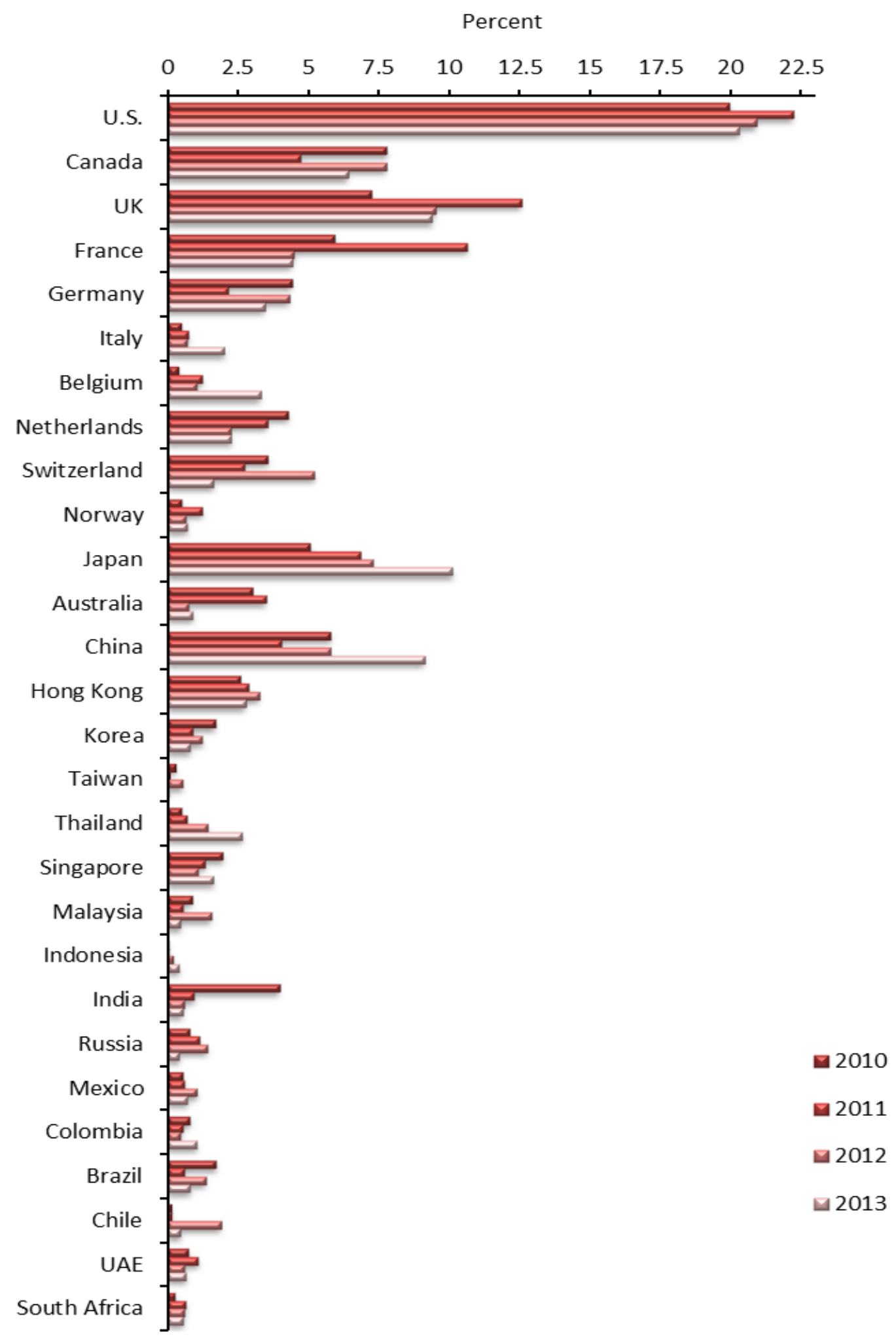

Figure 2. The ratios of the amount of acquiring firms of each country to the total amount of acquiring firms in the world: The international cases of 28 countries 
Table 2. The ratios of the amount of acquiring companies of each country to the total amount of acquiring companies in the world: 28 international cases from 2010 to 2013

\begin{tabular}{|c|c|c|c|c|}
\hline & \multicolumn{4}{|c|}{ Years } \\
\hline Countries & 2010 & 2011 & 2012 & 2013 \\
\hline U.S. & 19.9394 & 22.2033 & 20.9003 & 20.2947 \\
\hline Canada & 7.7623 & 4.7263 & 7.7377 & 6.4006 \\
\hline UK & 7.2203 & 12.5420 & 9.4908 & 9.3635 \\
\hline France & 5.9188 & 10.6408 & 4.4803 & 4.4037 \\
\hline Germany & 4.4085 & 2.1305 & 4.2961 & 3.4195 \\
\hline Italy & 0.4668 & 0.7457 & 0.6605 & 1.9895 \\
\hline Belgium & 0.3760 & 1.2210 & 1.0228 & 3.2863 \\
\hline Netherlands & 4.2812 & 3.5268 & 2.2231 & 2.2538 \\
\hline Switzerland & 3.5499 & 2.7122 & 5.2050 & 1.6077 \\
\hline Norway & 0.4881 & 1.2234 & 0.6351 & 0.6802 \\
\hline Japan & 5.0520 & 6.8333 & 7.2537 & 10.1020 \\
\hline Australia & 2.9938 & 3.4792 & 0.7415 & 0.8876 \\
\hline China & 5.7889 & 4.0250 & 5.7670 & 9.1107 \\
\hline Hong Kong & 2.5594 & 2.8477 & 3.2412 & 2.7505 \\
\hline Korea & 1.6793 & 0.8904 & 1.2143 & 0.7896 \\
\hline Taiwan & 0.2762 & 0.0826 & 0.5160 & 0.0469 \\
\hline Thailand & 0.4837 & 0.6579 & 1.4116 & 2.6411 \\
\hline Singapore & 1.9434 & 1.3316 & 1.0616 & 1.6008 \\
\hline Malaysia & 0.8712 & 0.5483 & 1.5367 & 0.4394 \\
\hline Indonesia & 0.0364 & 0.0298 & 0.1879 & 0.4113 \\
\hline India & 3.9728 & 0.9254 & 0.5789 & 0.5315 \\
\hline Russia & 0.7746 & 1.1255 & 1.4064 & 0.4083 \\
\hline Mexico & 0.5285 & 0.5948 & 1.0402 & 0.6993 \\
\hline Colombia & 0.7939 & 0.5271 & 0.4400 & 1.0269 \\
\hline Brazil & 1.6991 & 0.5717 & 1.3490 & 0.7912 \\
\hline Chile & 0.1323 & 0.1356 & 1.8875 & 0.4373 \\
\hline UAE & 0.7362 & 1.0681 & 0.6045 & 0.6526 \\
\hline South Africa & 0.2660 & 0.6453 & 0.5935 & 0.5502 \\
\hline
\end{tabular}

Notes: This table provides the global information with regard to the cross-border M\&As in international countries. More specifically, this table presents the ratios of the amount of acquiring companies of each country to the total amount of acquiring companies in the world. Information in this table is concerning the M\&As of 28 countries in the areas of North America, South America, Europe, Asia-Pacific, Russia, Middle East, and Africa. Moreover, the sample period is over the four years from 2010 to 2013. In this table, UAE denotes the United Arab Emirates and all values displayed in this table are presented in percent. 


\section{International Evidence of the Cross-border M\&As}

As explained in the previous sections, we constructed four kinds of variables with regard to the cross-border M\&As in the world. By carefully looking into the data, what kinds of characteristics are seen in the recent international cross-border M\&As? In this section, using the four kinds of variables, we aim to derive some clear international evidence on the recent global cross-border M\&As.

4.1 The Ratios of the Amount of Acquired Companies of Each Country to the Total Amount of Acquired Companies in the World: International Cases from 2010 to 2013

First, which countries' firms were bought by the executions of the recent cross-border M\&As? From Figure 1 and Table 1, we understand that, over the four years from 2010 to 2013, the larger amounts of acquired companies are observed in the six countries of the US, UK, Canada, Australia, Brazil, and Germany. The four year average ratios of the amount of acquired companies to the total amount of acquired companies as to the US, UK, Canada, Australia, Brazil, and Germany are 20.0308 percent, 10.9883 percent, 5.2505 percent, 5.1401 percent, 4.5378 percent, and 4.2328 percent, respectively. The above evidence means that recentry, the firms in the US, UK, Canada, Australia, Brazil, and Germany were more largely bought in the world.

4.2 The Ratios of the Amount of Acquiring Companies of Each Country to the Total Amount of Acquiring Companies in the World: International Cases from 2010 to 2013

Next, which countries' firms bought the other countries' firms by the implementations of the recent cross-border M\&As? Figure 2 and Table 2 indicate that, over the four years from 2010 to 2013, the larger amounts of acquiring companies are observed in the six countries of the US, UK, Japan, Canada, France, and China. Computing the four year average values of the ratios of the amounts of acquiring companies to the total amount of acquiring companies as to the US, UK, Japan, Canada, France, and China, they are 20.8344 percent, 9.6542 percent, 7.3102 percent, 6.6567 percent, 6.3609 percent, and 6.1729 percent, respectively. In particular, in the six countries, the acquiring ratios gradually increased in Japan in the recent years. The above evidence means that the firms of the US, UK, Japan, Canada, France, and China recently bought the other countries' firms more in the world.

4.3 Change Rates of the Ratio of the Amount of Acquiring Companies of Each Country to the Total Amount of Acquiring Companies in the World: International Cases from 2011 to 2013

Further, which countries' cross-border acquisitions were growing recently? Figure 3 and Table 3 display that in the year of 2012, the higher growth rates of the amounts of acquiring companies are seen in Chile, Indonesia, and Taiwan. Specifically, from 2011 to 2012, the growth rates as to Chile, Indonesia, and Taiwan are 1292.0536 percent, 530.6803 percent, and 524.4174 percent, respectively. Figure 3 and Table 3 also indicate that in the year of 2013, the higher growth rates of the amounts of acquiring companies are seen in Belgium, Italy, and Colombia. More concretely, from 2012 to 2013, the growth rates as to Belgium, Italy, and Colombia are 221.2901 percent, 201.2084 percent, and 133.4177 percent, respectively. On the other hand, in the year of 2013, Figure 3 and Table 3 show that the negative growth rates of the amounts of acquiring companies are observed in Taiwan, Chile, Malaysia, Russia, and Switzerland. Namely, from 2012 to 2013, the growth rates as to Taiwan, Chile, Malaysia, Russia, and Switzerland are -90.9164 percent, -76.8306 percent, -71.4088 percent, -70.9696 percent, and -69.1120 percent, respectively. We note that Chile and Taiwan recorded very high growth rates from 2011 to 2012; hence, the change rates became negative for a year from 2012 to 2013.

4.4 Differences between the Ratio of the Amount of Acquiring Companies to the Total Amount of Acquiring Companies and the Ratio of the Amount of Acquired Companies to the Total Amount of Acquired Companies: International Cases from 2010 to 2013

Finally, which countries' firms bid for the other countries' firms more than bought by the others in the recent cross-border M\&As? Figure 4 and Table 4 show that for the recent years, in Japan and China, the differences between the ratio of the amount of acquiring companies of each country to the total amount of acquiring companies in the world and the ratio of the amount of acquired companies of each country to the total amount of acquired companies in the world were positive. In 2013, the differences as to Japan and China are 8.7004 percent and 4.7089 percent, respectively. On the other hand, in the recent years, the differences between the ratio of the amount of acquiring companies of each country to the total amount of acquiring companies in the world and the ratio of the amount of acquired companies of each country to the total amount of acquired companies in the world were negative in Australia and Brazil. In 2013, the differences as to Australia and Brazil are -2.9479 percent and -2.0447 percent, respectively. Hence we understand that Japan and China recently executed larger amounts of cross-border M\&As as bidders whilst Australian and Brazilian firms were generally bought by the other countries' companies. 


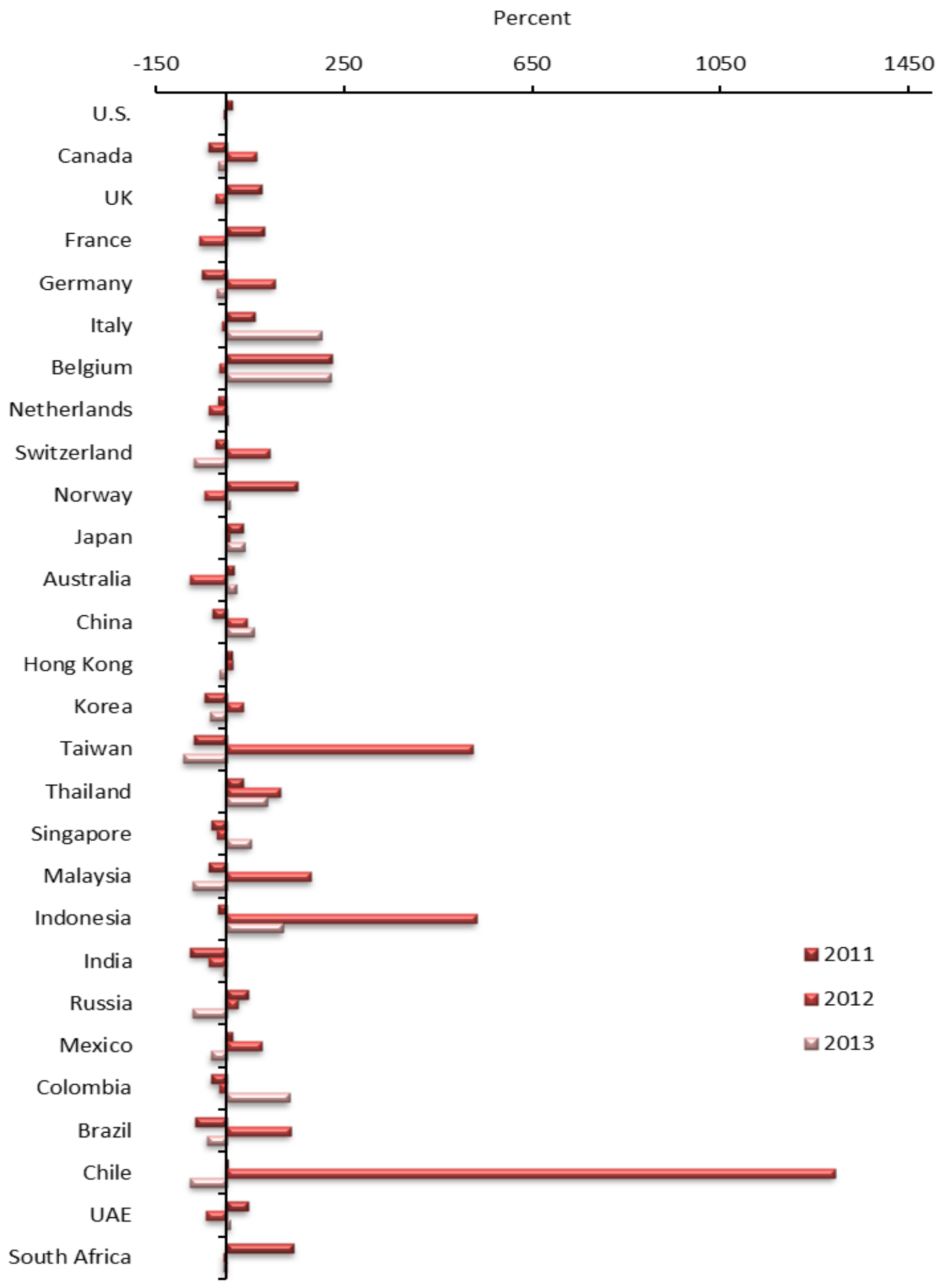

Figure 3. Change rates of the ratio of the amount of acquiring firms of each country to the total amount of acquiring firms in the world: The international cases of 28 countries 
Table 3. Change rates of the ratio of the amount of acquiring companies of each country to the total amount of acquiring companies in the world: 28 international cases from 2011 to 2013

\begin{tabular}{|c|c|c|c|}
\hline & & Years & \\
\hline Countries & 2011 & 2012 & 2013 \\
\hline U.S. & 11.3540 & -5.8686 & -2.8977 \\
\hline Canada & -39.1119 & 63.7167 & -17.2808 \\
\hline UK & 73.7035 & -24.3280 & -1.3409 \\
\hline France & 79.7783 & -57.8948 & -1.7104 \\
\hline Germany & -51.6732 & 101.6495 & -20.4044 \\
\hline Italy & 59.7387 & -11.4248 & 201.2084 \\
\hline Belgium & 224.7249 & -16.2308 & 221.2901 \\
\hline Netherlands & -17.6207 & -36.9647 & 1.3819 \\
\hline Switzerland & -23.5978 & 91.9089 & -69.1120 \\
\hline Norway & 150.6564 & -48.0899 & 7.1100 \\
\hline Japan & 35.2602 & 6.1516 & 39.2671 \\
\hline Australia & 16.2167 & -78.6876 & 19.6995 \\
\hline China & -30.4705 & 43.2795 & 57.9807 \\
\hline Hong Kong & 11.2656 & 13.8163 & -15.1383 \\
\hline Korea & -46.9793 & 36.3781 & -34.9750 \\
\hline Taiwan & -70.0791 & 524.4174 & -90.9164 \\
\hline Thailand & 36.0036 & 114.5805 & 87.0985 \\
\hline Singapore & -31.4796 & -20.2791 & 50.7915 \\
\hline Malaysia & -37.0675 & 180.2845 & -71.4088 \\
\hline Indonesia & -18.1103 & 530.6803 & 118.8981 \\
\hline India & -76.7075 & -37.4375 & -8.1856 \\
\hline Russia & 45.3062 & 24.9536 & -70.9696 \\
\hline Mexico & 12.5406 & 74.8873 & -32.7744 \\
\hline Colombia & -33.6155 & -16.5258 & 133.4177 \\
\hline Brazil & -66.3496 & 135.9437 & -41.3523 \\
\hline Chile & 2.5056 & 1292.0536 & -76.8306 \\
\hline UAE & 45.0865 & -43.4022 & 7.9519 \\
\hline South Africa & 142.5888 & -8.0294 & -7.3005 \\
\hline
\end{tabular}

Notes: This table provides the global information with regard to the cross-border M\&As in international countries. More specifically, this table presents the change rates of the ratio of the amount of acquiring companies of each country to the total amount of acquiring companies in the world. Information in this table is concerning the M\&As of 28 countries in the areas of North America, South America, Europe, Asia-Pacific, Russia, Middle East, and Africa. Moreover, the sample period is over the three years from 2011 to 2013. In this table, UAE denotes the United Arab Emirates and all values displayed in this table are presented in percent. 


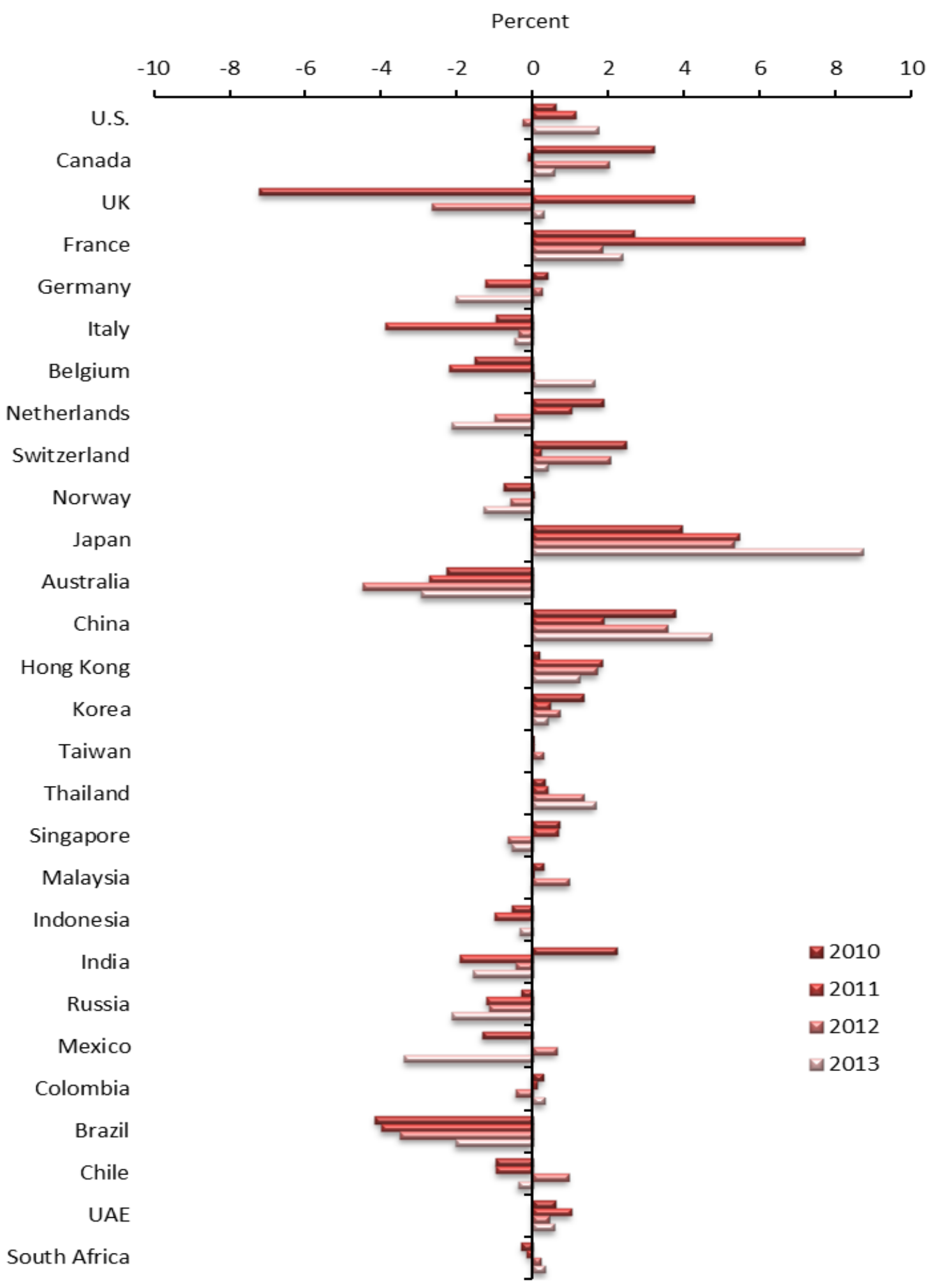

Figure 4. Differences between the ratio of the amount of acquiring firms to the total amount of acquiring firms and the ratio of the amount of acquired firms to the total amount of acquired firms: International evidence 
Table 4. Differences between the ratio of the amount of acquiring companies to the total amount of acquiring companies and the ratio of the amount of acquired companies to the total amount of acquired companies: 28 international cases from 2010 to 2013

\begin{tabular}{|c|c|c|c|c|}
\hline & \multicolumn{4}{|c|}{ Years } \\
\hline Countries & 2010 & 2011 & 2012 & 2013 \\
\hline U.S. & 0.6170 & 1.1383 & -0.2634 & 1.7228 \\
\hline Canada & 3.1950 & -0.1508 & 2.0194 & 0.5612 \\
\hline UK & -7.2254 & 4.2589 & -2.6491 & 0.2789 \\
\hline France & 2.6784 & 7.1713 & 1.8233 & 2.3574 \\
\hline Germany & 0.3766 & -1.2479 & 0.2444 & -2.0496 \\
\hline Italy & -0.9795 & -3.8854 & -0.3745 & -0.4872 \\
\hline Belgium & -1.5256 & -2.2005 & 0.0020 & 1.6208 \\
\hline Netherlands & 1.8781 & 1.0131 & -1.0080 & -2.1525 \\
\hline Switzerland & 2.4617 & 0.2277 & 2.0231 & 0.4043 \\
\hline Norway & -0.7819 & 0.0422 & -0.6008 & -1.2911 \\
\hline Japan & 3.9338 & 5.4351 & 5.2997 & 8.7004 \\
\hline Australia & -2.2625 & -2.7495 & -4.4984 & -2.9479 \\
\hline China & 3.7416 & 1.8687 & 3.5423 & 4.7089 \\
\hline Hong Kong & 0.1711 & 1.8170 & 1.7044 & 1.2152 \\
\hline Korea & 1.3405 & 0.4470 & 0.7203 & 0.3914 \\
\hline Taiwan & 0.0355 & 0.0193 & 0.2727 & -0.0603 \\
\hline Thailand & 0.3136 & 0.3913 & 1.3497 & 1.6376 \\
\hline Singapore & 0.6890 & 0.6566 & -0.6712 & -0.5675 \\
\hline Malaysia & 0.2973 & 0.0034 & 0.9580 & -0.0633 \\
\hline Indonesia & -0.5486 & -1.0070 & -0.0274 & -0.3553 \\
\hline India & 2.2203 & -1.9361 & -0.4475 & -1.5896 \\
\hline Russia & -0.3084 & -1.2315 & -1.1399 & -2.1311 \\
\hline Mexico & -1.3354 & -0.0270 & 0.6269 & -3.3881 \\
\hline Colombia & 0.2669 & 0.1205 & -0.4579 & 0.3071 \\
\hline Brazil & -4.1668 & -4.0146 & -3.5143 & -2.0447 \\
\hline Chile & -0.9866 & -0.9764 & 0.9490 & -0.3881 \\
\hline UAE & 0.5840 & 1.0102 & 0.4395 & 0.5671 \\
\hline South Africa & -0.3100 & -0.1725 & 0.2077 & 0.3283 \\
\hline
\end{tabular}

Notes: This table provides the global information with regard to the cross-border M\&As in international countries. More specifically, this table presents the differences between the ratio of the amount of acquiring companies of each country to the total amount of acquiring companies in the world and the ratio of the amount of acquired companies of each country to the total amount of acquired companies in the world. Information in this table is concerning the M\&As of 28 countries in the areas of North America, South America, Europe, Asia-Pacific, Russia, Middle East, and Africa. Moreover, the sample period is over the four years from 2010 to 2013. In this table, UAE denotes the United Arab Emirates and all values displayed in this table are presented in percent. 


\section{Conclusions}

The objective of this study was to provide a simple and clear overview of M\&As, which are useful for smooth entire understanding of the recent state and evolution of the cross-border M\&As in the world. For this purpose, this paper broadly investigated the international cross-border M\&As and our analyses found the following clear evidence. First, we revealed that, 1) over the four years from 2010 to 2013, the larger amounts of acquired companies were observed in the six countries of the US, UK, Canada, Australia, Brazil, and Germany. This means that the firms in the US, UK, Canada, Australia, Brazil, and Germany were more largely bought by the other countries' firms in the world. Second, we found that, 2) over the four years from 2010 to 2013, the larger amounts of acquiring companies were observed in the six countries of the US, UK, Japan, Canada, France, and China. This means that the firms in the US, UK, Japan, Canada, France, and China more actively bought the other countries' firms in the world.

Moreover, we further clarified that 3) for the recent years, in Japan and China, the differences between the ratio of the amount of acquiring companies of the country to the total amount of acquiring companies in the world and the ratio of the amount of acquired companies of the country to the total amount of acquired companies in the world were positive. On the other hand, in the recent years, the differences between the ratio of the amount of acquiring companies of the country to the total amount of acquiring companies in the world and the ratio of the amount of acquired companies of the country to the total amount of acquired companies in the world were negative in Australia and Brazil. The evidence demonstrates that the firms in Japan and China executed larger amounts of cross-border M\&As as bidders whilst Australian and Brazilian firms were generally bought by the other countries' companies in the cross-border M\&As.

We consider that the detailed specific researches of M\&As as we reviewed in our literature review section are indeed important while our current study is also informative and useful because this study supplies broad information to understand the recent evolution of the cross-border M\&As executed around the world. Further rigorous analysis and specific case studies as to the cross-border M\&As shall be our future works.

\section{Acknowledgements}

I am particularly grateful to the kind repeated invitation from the journal to write to this journal. I also appreciate the Japan society for the promotion of science, Zengin Foundation for Studies on Economics and Finance, and the Chuo university grant for special research for their generous financial assistance to this research. Finally, I deeply thank the Editors of this journal and Jenny Zhang for their kindness to this paper.

\section{References}

Ahammad, M. F., Tarba, S. Y., Liu, Y., \& Glaister, K. W. (2015). Knowledge transfer and cross-border acquisition performance: The impact of cultural distance and employee retention. International Business Review, forthcoming. http://dx.doi.org/10.1016/j.ibusrev.2014.06.015

Andriosopoulos, D., \& Yang, S. (2015). The impact of institutional investors on mergers and acquisitions in the United Kingdom. Journal of Banking \& Finance, 50, 547-561. http://dx.doi.org/10.1016/j.jbankfin.2014.06.004

Angwin, D. N., Paroutis, S., \& Connell, R. (2015). Why good things Don't happen: the micro-foundations of routines in the M\&A process. Journal of Business Research, forthcoming. http://dx.doi.org/10.1016/j.jbusres.2014.12.007

Bauer, F., Matzler, K., \& Wolf, S. (2015). M\&A and innovation: The role of integration and cultural differences-A central European targets perspective. International Business Review, forthcoming. http://dx.doi.org/10.1016/j.ibusrev.2014.07.010

Blonigen, B. A., Fontagné, L., Sly, N., \& Toubal, F. (2014). Cherries for sale: The incidence and timing of cross-border M\&A. Journal of International Economics, 94, 341-357. http://dx.doi.org/10.1016/j.jinteco.2014.08.005

Chung, G. H., Du, J., \& Choi, J. N. (2014). How do employees adapt to organizational change driven by cross-border M\&As? A case in China. Journal of World Business, 49, 78-86. http://dx.doi.org/10.1016/j.jwb.2013.01.001

Deng, P., \& Yang, M. (2015). Cross-border mergers and acquisitions by emerging market firms: A comparative investigation. International Business Review, 24, 157-172. http://dx.doi.org/10.1016/j.ibusrev.2014.07.005

Du, M., \& Boateng, A. (2015). State ownership, institutional effects and value creation in cross-border mergers \& acquisitions by Chinese firms. International Business Review, forthcoming. http://dx.doi.org/10.1016/j.ibusrev.2014.10.002 
Dunn, J. K., Intintoli, V. J., \& McNutt, J. J. (2015). An examination of non-government-assisted US commercial bank mergers during the financial crisis. Journal of Economics and Business, 77, 16-41. http://dx.doi.org/10.1016/j.jeconbus.2014.09.002

Francis, B. B., Hasan, I., \& Sun, X. (2014). The certification role of financial advisors in cross-border M\&As. International Review of Financial Analysis, 32, 143-158. http://dx.doi.org/10.1016/j.irfa.2014.01.003

Gregory, A., \& O'Donohoe, S. (2014). Do cross border and domestic acquisitions differ? Evidence from the acquisition of UK targets. International Review of Financial Analysis, 31, 61-69. http://dx.doi.org/10.1016/j.irfa.2013.09.001

Lee, S. J., Kim, J., \& Park, B. I. (2015). Culture clashes in cross-border mergers and acquisitions: A case study of Sweden's Volvo and South Korea's Samsung. International Business Review, forthcoming. http://dx.doi.org/10.1016/j.ibusrev.2014.10.016

Ning, L., Kuo, J. M., Strange, R., \& Wang, B. (2014). International investors' reactions to cross-border acquisitions by emerging market multinationals. International Business Review, 23, 811-823. http://dx.doi.org/10.1016/j.ibusrev.2013.12.003

Zhu, H., Xia, J., \& Makino, S. (2015). How do high-technology firms create value in international M\&A? Integration, autonomy and cross-border contingencies. Journal of World Business, forthcoming. http://dx.doi.org/10.1016/j.jwb.2015.01.001 